\title{
CAPITAL
}

JURNAL EKONOMI DAN MANAJEMEN

P-ISSN: 2598-9022/ E-ISSN: 2598-9618

Available at: http://e-journal.unipma.ac.id/index.php/capital

\section{Analisis Penerimaan Teknologi Mobile Banking Terhadap Use Behavior Melalui Pendekatan Model Utaut 2 (Studi Pada Nasabah KCU BCA Malang)}

\author{
Wira Bharata Premi ${ }^{1)}$,Wahyu Widyaningrum ${ }^{2)}$ \\ ${ }^{1}$ Fakultas Ilmu Sosial dan Politik, Universitas Mulawarman \\ email: wira.bharata@gmail.com \\ ${ }^{2}$ Fakultas Ekonomi, Universitas Muhammadiyah Ponorogo \\ email: premi.wahyu@gmail.com
}

\begin{abstract}
The development of internet technology is also adopted by state and private banks to develop services. Internet banking is a revolutionary and strategic weapon for bank operations, product delivery, and to face competition between banks. The security and convenience of conducting transactions is a key driver for mobile banking growth. The presence of smartphones supports more types of online banking services. This study was conducted to predict the acceptance and adoption of information technology, especially mobile banking to bank customers. The approach of this research is quantitative research approach. The type of research used is survey research. Samples were taken using simple random sampling. The sample size was determined by 53 people, using the Machin and Chambel formula. The population in this research is KCU BCA Malang customer. Empirical data were collected through survey methodology. The data will be analyzed through the Generalized Structured Component Analysis (GSCA). Research findings indicate that there are positive outcomes of all relationships measured.
\end{abstract}

Keywords: UTAUT, Mobile Banking, Behavioral Intention, Use Behavior.

\begin{abstract}
Abstrak
Perkembangan teknologi internet juga diadopsi oleh bank pemerintah dan swasta untuk mengembangkan layanan. Perbankan internet adalah senjata revolusioner dan strategis untuk operasi bank, pengiriman produk, dan untuk menghadapi persaingan antar bank. Keamanan dan kenyamanan melakukan transaksi adalah pendorong utama untuk pertumbuhan mobile banking. Kehadiran smartphone mendukung lebih banyak jenis layanan perbankan online. Penelitian ini dilakukan untuk memprediksi penerimaan dan adopsi teknologi informasi, terutama mobile banking kepada nasabah bank. Pendekatan penelitian ini adalah pendekatan penelitian kuantitatif. Jenis penelitian yang digunakan adalah penelitian survei. Sampel diambil menggunakan quota sampling. Ukuran sampel ditentukan oleh 53 orang, menggunakan rumus Machin dan Chambel. Populasi dalam penelitian ini adalah pelanggan KCU BCA Malang. Data empiris dikumpulkan melalui metodologi survei. Data akan dianalisis melalui Generalized Structured Component Analysis (GSCA). Temuan penelitian menunjukkan bahwa ada hasil positif dari semua hubungan yang diukur.
\end{abstract}

Kata Kunci: UTAUT, Mobile Banking, Behavioral Intention, Use Behavior. 


\section{A. PENDAHULUAN}

Media internet adalah suatu inovasi terkini yang memberi peluang dan menantang dalam pengembangannya. Peluang ini dimanfaatkan oleh industri perbankan yang ada di Indonesia. Perkembangan teknologi internet juga diadopsi oleh bank pemerintah maupun swasta untuk mengembangkan pelayanan. Perkembangan pelayanan yang dilakukan perbankan berbasis teknologi (electronic transaction) dalam bentuk internet banking, mobile banking yang berbasis handphone, penggunaan ATM (Authomatic Teller Machine), Credit Card dan lain sebagainya merupakan keharusan bagi bank-bank di Indonesia untuk merebut pangsa pasar.

Internet banking merupakan senjata yang revolusioner dan strategis bagi kegiatan operasional bank, mendelivery produk, maupun untuk menghadapi persaingan antar bank. Online banking diperkenalkan sebagai channel dimana nasabah bank dapat melakukan aktivitas finansial perbankan secara digital melalui website bank. Nasabah dapat melakukan transaksi non cash setiap saat dengan mudah dan nyaman melalui komputer (jaringan internet). Inovasi pelayanan perbankan melalui teknologi internet banking diharapkan dapat menekan transactional cost dan antrian yang terjadi di kantor-kantor bank.

Internet banking dapat digunakan untuk bermacam-macam transaksi online yaitu: 1) untuk mengecek saldo rekening dan history transaksi bank; 2) membayar macam-macam tagihan; 3) transfer antar account. Namun, nasabah bank di Indonesia masih banyak yang menggunakan internet banking hanya sekedar untuk melihat saldo. Pihak bank perlu meningkatkan strategi agar semakin banyak nasabah yang menggunakan internet banking dengan tujuan agar value yang diberikan nasabah bank semakin tinggi. Transaksi $e$ payment dapat lebih dikembangkan dalam aktivitas bisnis sehingga nasabah bank benar benar merasakan manfaat internet banking ini.

Penetrasi luas dan sifat pribadi handphone, perkembangan teknologi komunikasi seluler yang pesat, dan pengalaman positif menggunakan m-commerce adalah alasan utama kemunculan aplikasi mobile yang dibuat berlaku untuk berbagai jasa keuangan. Aplikasi keuangan mobile yang ada saat ini dan paling sering digunakan adalah mobile banking. Mobile banking menyediakan beberapa solusi transaksi alternatif yang berbeda dengan transaksi secara konvensional. Dewasa ini, menggunakan layanan mobile banking untuk 
membayar tagihan, melakukan transaksi jual beli, atau sekedar membeli pulsa sangat lazim dilakukan oleh masyarakat.

Keamanan dan kenyamanan melakukan transaksi adalah pendorong utama bagi pertumbuhan mobile banking. Dalam hal mengidentifikasi pembayaran maupun mengkonfirmasi transaksi, mobile banking sangat efektif digunakan. Dalam bentuk yang paling sederhana, layanan mobile banking memungkinkan pengguna untuk menerima informasi saldo rekening mereka via SMS. Kehadiran smartphone mendukung lebih banyak jenis layanan perbankan seperti transfer dana antar rekening, perdagangan saham, maupun pembelian tiket secara online.

Suatu produk atau jasa sudah tersedia sejak beberapa waktu yang lalu, tetapi yang penting bagi bank adalah memahami perilaku konsumen belajar tentang produk untuk pertama kalinya dan memutuskan apakah akan mengadopsinya, karena fasilitas mobile banking tergolong baru bagi masyarakat mengetahui faktor-faktor apa saja yang bisa mempengaruhi konsumen menggunakan fasilitas yang telah disediakan bank,diharapkan mampu memberikan nilai tambah yang maksimal bagi konsumen, pada akhirnya memberikan keunggulan bersaing (competitive advantage) bagi perusahaan.

Sistem teknologi informasi dapat dikatakan berhasil apabila diterima dengan baik oleh user. Merubah suatu perilaku user tidak dapat dilakukan secara langsung ke perilakunya, tetapi harus diidentifikasikan terlebih dahulu penentu atau penyebab perilaku tersebut. Pengidentifikasian faktor penentu penerimaan teknologi informasi menjadi hal penting untuk pengembangan sistem informasi. Hal ini perlu dilakukan agar investasi yang tinggi terhadap fasilitas teknologi informasi tersebut menjadi bermanfaat dan mampu memberikan nilai bagi konsumen maupun bagi perusahaan.

Berbagai permasalahan tersebut mendorong peneliti untuk mengadakan penelitian mengenai penerimaan teknologi informasi oleh pengguna dengan menggunakan model Teori Terpadu Penerimaan dan Penggunaan Teknologi (Unified Unified Theory of Acceptance and Use of Technology atau UTAUT) yang dikembangkan oleh Venkatesh et. al. (2012). Penelitian ini dilakukan untuk memprediksi penerimaan dan adopsi teknologi informasi khususnya mobile banking pada nasabah bank. Peneliti mengambil judul Analisis Penerimaan teknologi mobile banking terhadap use behavior melalui pendekatan Model UTAUT 2 (Studi pada nasabah BCA cabang Malang). 
Berdasarkan latar belakang masalah di atas dan untuk memperjelas pokok pembahasan pada penelitian ini, maka masalah dalam penelitian ini dapat dirumuskan sebagai berikut:

1) Apakah Ekspektasi Kinerja berpengaruh positif dan signifikan terhadap Minat Pemanfaatan?

2) Apakah Ekspektasi Usaha berpengaruh positif dan signifikan terhadap Minat Pemanfaatan?

3) Apakah Faktor Sosial berpengaruh positif dan signifikan terhadap Minat Pemanfaatan?

4) Apakah Kondisi Pemfasilitasi berpengaruh positif dan signifikan terhadap Minat Pemanfaatan?

5) Apakah Kondisi Pemfasilitasi berpengaruh positif dan signifikan terhadap Penggunaan?

6) Apakah Motivasi Hedonik berpengaruh positif dan signifikan terhadap Minat Pemanfaatan?

7) Apakah Nilai Harga berpengaruh positif dan signifikan terhadap Minat Pemanfaatan?

8) Apakah Kebiasaan berpengaruh positif dan signifikan terhadap Minat Pemanfaatan?

9) Apakah Kebiasaan berpengaruh positif dan signifikan terhadap Penggunaan?

10) Apakah Minat Pemanfaatan TI berpengaruh positif dan signifikan terhadap Penggunaan?

\section{B. TINJAUAN PUSTAKA}

\section{Sistem Informasi Manajemen}

Sistem informasi merupakan kombinasi teratur dari manusia, hardware, software, jaringan komunikasi, dan sumber daya data yang mengumpulkan, mengubah, dan menyebarkan informasi dalam sebuah organisasi. Manusia bergantung pada sistem informasi untuk berkomunikasi antara satu sama lain dengan menggunakan berbagai jenis alat fisik (hardware), perintah dan prosedur pemrosesan informasi (software), saluran 
komunikasi (jaringan), dan data yang disimpan (sumber daya data) sejak permulaan peradaban (O’Brief, 2008 h. 5).

Sistem informasi dan organisasi saling mempengaruhi. Sistem informasi harus disesuaikan dengan organisasi agar memberikan informasi yang dibutuhkan pada suatu bagian tertentu yang penting pada organisasi. Pada saat yang sama, organisasi harus waspada dan terbuka terhadap pengaruh sistem informasi supaya mendapat keuntungan dari teknologi baru (Laudon dan Laudon 2009 h. 101). Interaksi antara teknologi informasi dan organisasi sangat kompleks dan dipengaruhi oleh banyak faktor mediasi yang besar, yaitu struktur organisasi, prosedur operasi standar, politik, kultur, lingkungan sekitar, dan keputusan manajemen, seperti pada gambar berikut (Laudon dan Laudon, 2009 h.101).

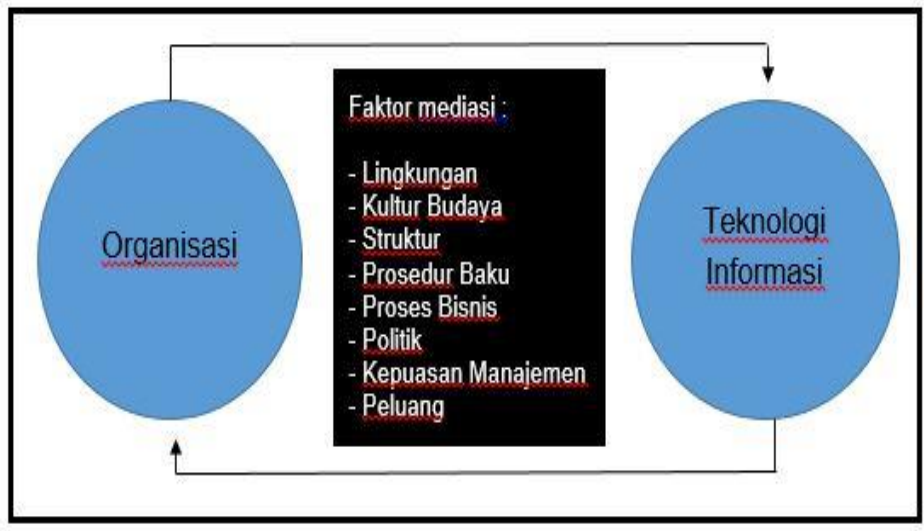

sumber: Laudon dan Laudon (2009)

\section{Gambar 1. Interaksi Organisasi dan Teknologi Informasi}

Tanpa pemahaman akan organisasi, dalam faktor lingkungan, kultur, struktur, prosedur kerja, proses, politik, keinginan manajemen, dan peluang organisasi mustahil implementasi sistem informasi dapat berjalan. Membangun sistem informasi yang baru atau membangun ulang sistem yang sudah ada, melibatkan lebih dari sekadar pengaturan kembali mesin atau pekerja. Sebagian sistem informasi mengubah keseimbangan organisasi atas hak, hak khusus, kewajiban, tanggung jawab, dan daya perasaan yang sudah terbentuk selama periode waktu tertentu (Laudon dan Laudon, 2009 h. 103).

Banyak orang tidak menyukai perubahan. Resistensi pemakai akhir (end user resistance) bisa terjadi ketika organisasi mulai mengadopsi teknologi informasi baru. Pekerja sering segan, bahkan takut menggunakan teknologi informasi. O'Brief (2008 h. 545) menuliskan bahwa organisasi perlu memiliki berbagai strategi untuk membantu 
mengelola perubahan, dan satu persyaratan dasar adalah keterlibatan dan komitmen manajemen puncak dan semua pihak yang berkepentingan dengan organisasi yang dipengaruhi oleh aplikasi teknologi informasi yang baru.

\section{Penerimaan Teknologi Informasi}

Teknologi informasi dapat mengubah organisasi dan orang-orang yang terlibat di dalamnya. Supaya teknologi informasi dapat meningkatkan kinerja organisasi, teknologi harus dapat diterima untuk digunakan oleh para pemakai akhirnya. Penelitian sistem informasi telah lama mempelajari bagaimana dan mengapa individu mengadopsi teknologi informasi baru. Dalam cakupan penyelidikan yang luas, sudah ada beberapa aliran penelitian (Venkatesh, 2003) Gambar berikut menyajikan kerangka konseptual dasar yang mendasari model penerimaan individu teknologi informasi.

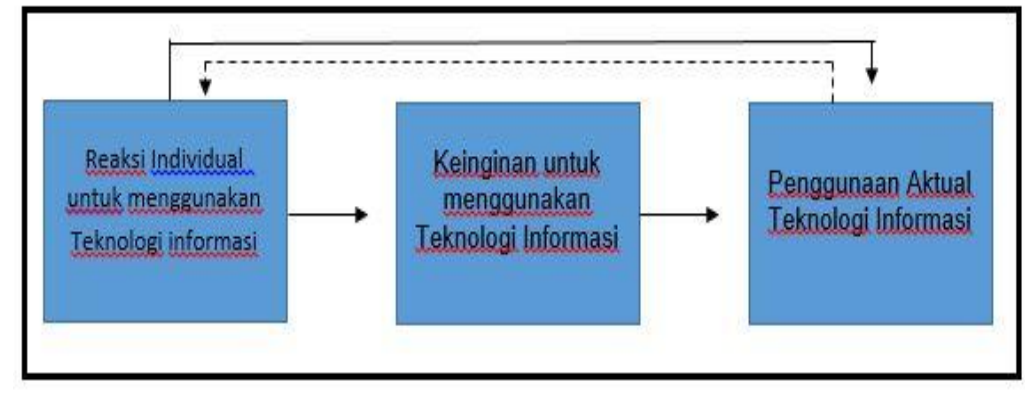

sumber: Venkatesh (2003)

\section{Gambar 2. Model Penerimaan Pemakai Teknologi Informasi}

Venkatesh et. al. (2003) mengadakan studi lapangan longitudinal. Studi tersebut dilakukan di empat organisasi ketika individu-individu yang mempergunakan teknologi baru di tempat kerja. Dengan menggunakan sebuah kuesioner pretested berisi item untuk mengukur konstruksi dari semua model. Kuesioner diberikan pada tiga titik berbeda dalam waktu: pasca-pelatihan, satu bulan setelah pelaksanaan, dan tiga bulan setelah pelaksanaan. Perilaku penggunaan aktual diukur setelah enam bulan setelah periode pelatihan. Venkatesh et. al. (2003) merumuskan Teori Terpadu Penerimaan dan Penggunaan Teknologi (Unified Theory of Acceptance and Use of Technology/UTAUT).Venkatesh dkk (2003) berteori bahwa empat konstruksi akan memainkan peran penting sebagai penentu langsung dari penerimaan pengguna dan perilaku penggunaan: ekspektasi kinerja (performance 
expectancy), ekspektasi usaha (effort expectancy), pengaruh sosial (social influence), dan kondisi yang memfasilitasi (facilitating conditions).

\section{Pemanfaatan Teknologi Informasi}

Teknologi informasi merupakan satu dari sekian banyak alat bantu yang digunakan para manajer untuk menjembatani perubahan (Laudon dan Laudon, 2005 h. 18). Perangkat keras dan perangkat lunak komputer serta teknologi penyimpanan data, dan jaringan yang bisa dibagikan di seluruh organisasi ikut membangun infrastruktur teknologi informasi. Infrastruktur TI menyediakan dasar atau platform agar organisasi bisa membangun sistem informasi yang khas. Teknologi informasi memainkan peran penting dalam perekayasaan ulang sebagian besar proses bisnis. Kecepatan, kemampuan pemrosesan informasi, dan konektivitas komputer dapat secara mendasar meningkatkan efisiensi proses operasi serta meningkatkan komunikasi dan kerja sama antar orang-orang yang bertanggung jawab atas operasi dan manajemennya (O’Brief 2008 h. 76).

Teknologi informasi merupakan komponen penting dalam keberhasilan bisnis perusahaan saat ini. Akan tetapi teknologi informasi juga merupakan sumber daya bisnis penting yang harus dikelola dengan benar (O’Brief ,2008 h. 631). Selain itu, kita juga telah melihat banyak contoh dari dunia nyata dengan teknologi informasi memainkan peranan penting dalam memastikan keberhasilan ataupun kegagalan usaha bisnis strategis perusahaan. Dapat disimpulkan, mengelola sistem dan teknologi informasi yang mendukung proses bisnis modern perusahaan saat ini, adalah tantangan besar para manajer bisnis dan TI, serta para praktisi bisnis.

\section{Minat Perilaku (Behavioral Intention)}

Minat perilaku (Behavioral intention) dan perilaku (behavior) adalah dua hal yang berbeda.Minat atau intense (intention) diartikan sebagai keinginan untuk melakukan perilaku. Minat tidak selalu statis. Minat dapat berubah dengan berjalannya waktu (Hartanto, 2007: 29 dalam Hormati, 2012: 22). Minat perilaku masih merupakan suatu minat dan belum berupa perilaku. Sementara perilaku adalah tindakan atau kegiatan nyata yang dilakukan (Hormati, 2012: 22). Theory of Reasoned Action (TRA) menjelaskan bahwa

perilaku (behavior) dilakukan karena individual mempunyai minat atau keinginan untuk 
melakukannya. Minat merupakan suatu fungsi dari dua penentu dasar, yang satu berhubungan dengan faktor pribadi dan yang lainnya berhubungan dengan pengaruh sosial. Penentu pertama yang berhubungan dengan faktor pribadi adalah sikap terhadap perilaku (attitude toward the behavior) individual. Sikap ini adalah evaluasi kepercayaan (belief) atau perasaan (affect) positif atau negatif dari individu jika harus melakukan perilaku tertentu yang dikehendaki.

Hasil penelitian Venkatesh dan Davis (2000), menunjukkan bahwa minat perilaku (behavioral intention) merupakan prediksi yang baik dari penggunaan teknologi oleh pemakai sistem. Keputusan yang dilakukan oleh individu untuk menerima suatu teknologi sistem informasi merupakan tindakan sadar yang dapat dijelaskan dan diprediksi oleh minat perilakunya. Penerimaan individual terhadap sistem teknologi informasi ditentukan oleh dua konstruk, yaitu kegunaan persepsian (perceived usefulness) dan kemudahan penggunaan persepsian (perceived ease of use). Keduanya mempunyai pengaruh ke minat perilaku (behavioral intention). Pemakaian teknologi akan mempunyai minat menggunakan teknologi (minat perilaku) jika merasa sistem teknologi bermanfaat dan mudah digunakan (Hormati, 2012: 23).

\section{Model UTAUT 2}

Penggunaan teknologi informasi merupakan suatu refleksi dari perilaku seseorang.Perilaku seseorang dapat dilihat dari minat mereka untuk menggunakan suatu sistem teknologi informasi. Seseorang akan menggunakan sistem jika mereka percaya bahwa sistem tersebut berguna dalam membantu penyelesaian pekerjaannya. Sebaliknya, jika seseorang merasa bahwa mmenggunakan sistem tidak membawa dampak yang baik bagi pekerjaanya, mereka tidak akan mengunakan sistem tersebut. Penggunaan nyata dalam penelitian ini adalah seberapa lama pemakai berinteraksi dengan sistem informasi atau menggunakan sistem tersebut untuk menyelesaikan perkerjaannya (Hormati, 2012: 24).

DeLone dan McLean (1992 dalam Hormati, 2012: 24) menyatakan bahwa penggunaan dan kepuasan user berhubungan erat. Konsep penggunaan (use) dari suatu sistem dapat dilihat dari beberapa perspektif, yaitu penggunaan nyata (actual use) dan penggunaan persepsian (perceived use) atau penggunaan yang dilaporkan sendiri (reported use).Berikut 
model Teori Terpadu Penerimaan dan Penggunaan Teknologi (Unified Theory of Acceptance and Use of Technology/UTAUT) yang dibuat oleh Venkatesh et. al. (2003)

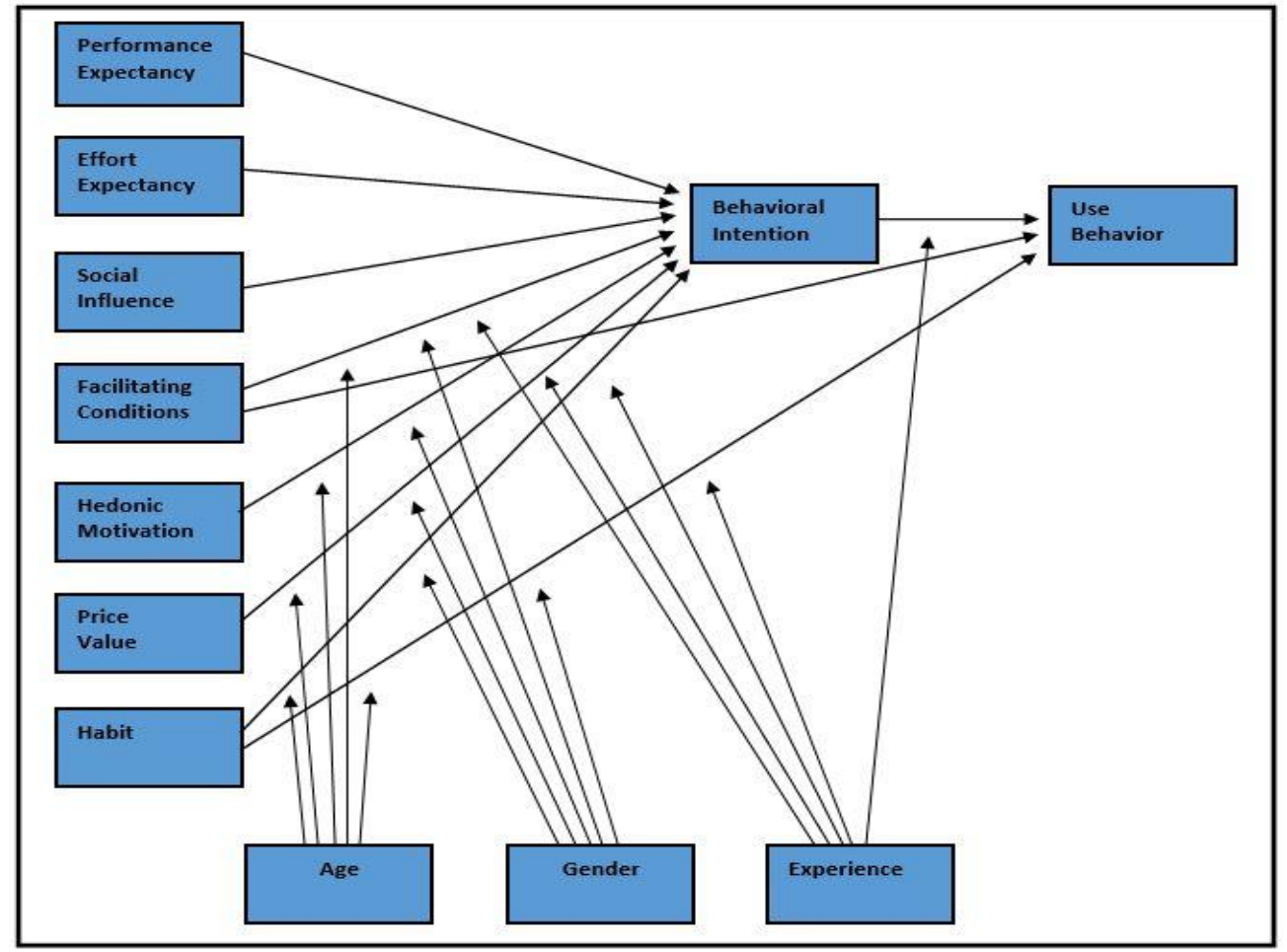

sumber: Venkatesh (2012)

\section{Gambar 3. Model UTAUT 2}

\section{Mobile Banking}

Mobile banking, juga disebut sebagai ponsel banking, adalah penggunaan terminal mobile seperti ponsel dan personal digitalassistant (PDA) untuk mengakses jaringan perbankan melalui wireless application protocol (WAP). Luarn \& Lin, (2005, dalam Zhao, 2010: 7) menjelaskan bahwa melalui mobile banking pengguna dapat mengakseslayanan perbankan seperti manajemen akun, permintaan informasi, transfer uang, dan pembayaran tagihan.Dibandingkan dengan layanan perbankan online berbasis internet yang lain, mobile banking ini bebas dari kendala temporal dan spasial. Pengguna dapat memperolehinformasi akun real time dan melakukan pembayaran kapan sajadan dimana saja.

Junglas \& Watson (2006 dalam Zhao, 2010: 11) mengatakan mobile banking dibangun pada jaringan nirkabel menggunakan protokol seperti layanan paket umum radio (GPRS) dan kode beberapa divisi Akses (CDMA). Mobile Banking merupakan suatu aplikasi yang mendukung nasabah dalam mewujudkan keinginannya untuk dapat melakukan kegiatan 
transaksi perbankan melalui smartphone. Masuknya mobile banking dalam dunia perbankan ini memberikan dampak positif bagi nasabah dalam melakukan kegiatan transaksi perbankan. Nasabah tidak lagi harus melakukan transaksi perbankan dengan cara datang ke bank. Nasabah hanya perlu menggunakan smartphone miliknya, baik handphone maupun tablet, dengan dihubungkan melalui internet untuk dapat menjalankan aplikasi mobile banking.

Menurut Levy and Weitz (2012, p.80) "The buying process begins when customers recognize an unsatisfied need. Then they seek information about how to satisfy the need: what products might be useful and how they can be bought". Proses pembelian dimulai saat pelanggan mengetahui kebutuhannya belum terpuaskan. Dimulai dengan proses pencarian informasi, hal ini dilakukan dengan mengumpulkan semua informasi yang berhubungan dengan produk yang diinginkan.

\section{METODE PENELITIAN}

Penelitian ini termasuk penelitian eksplanatoris (explanatory research) dengan pendekatan kuantitatif, yaitu penelitian yang berupaya menjelaskan hubungan kausal antara variabel-variabel melalui pengujian hipotesis (Singarimbun dan Effendi, 1995). Pendekatan kuantitatif dilandasi pada suatu asumsi bahwa suatu gejala itu dapat diklasifikasikan, dan hubungan gejala bersifat kausal (sebab akibat) antara variabel atau konstruk melalui pengujian hipotesis (Sugiyono, 2010).

Metode penelitian yang digunakan penelitian menggunakan metode survei, yaitu metode yang digunakan untuk memperoleh informasi melalui permintaan keteranganketerangan kepada responden dengan menggunakan kuesioner sebagai alat pengumpul data utama (primer). Pada umumnya yang merupakan unit analisis dalam penelitian survei adalah individu (Singarimbun dan Effendi, 1995). Unit analisis dalam penelitian ini adalah nasabah BCA yang menggunakan mobile banking.

Penelitian ini menganalisis bukti data yang dikumpulkan dari nasabah BCA yang menggunakan mobile banking. Penelitian ini bertempat di KCU BCA Malang, Jl. Jendral Basuki Rachmat 70-74 kota Malang, Jawa Timur. Alasan pemilihan lokasi penelitian

adalah dikarenakan lokasi tersebut merupakan kantor utama BCA di kota Malang yang mempunyai lebih banyak jumlah nasabah dibanding kantor BCA yang lain. 
Populasi adalah wilayah generalisasi yang terdiri atas objek/subjek yang mempunyai kualitas dan karakteristik tertentu yang ditetapkan oleh peneliti untuk dipelajari dan kemudian ditarik kesimpulannya (Sugiyono, 2012 h. 61). Populasi dalam penelitian ini adalah seluruh nasabah KCU BCA Malang.Metode pengambilan sampel yang digunakan adalah metode nonprobability sampling.

Teknik pengambilan sampel yang digunakan adalah quota sampling. Jumlah populasi dalam penelitian ini tidak diketahui, maka untuk menentukan jumlah sampel digunakan rumus Machin and Chambell (1997; 169). Berdasarkan pertimbangan bahwa nilai terendah yang diperkirakan akan diperoleh melalui penelitian ini adalah $r=0,45$; kemudian $\alpha=0,5$ Z1- $\alpha=1,645$ pada pengukuran dua arah, dan $\beta=0,5$ Z1- $\beta=1,645$ maka diperoleh $n$ $($ minimum $)=53,21$. Sehingga dalam penelitian ini mengambil sampel minimal 53orang responden. Dalam penelitian ini kriteria sampel adalah:

1) Sampel merupakan nasabah BCA Cabang Malang.

2) Sampel telah menggunakan aplikasi mobile banking.

Penelitian mengadopsi Teori Terpadu Penerimaan dan Penggunaan Teknologi (Unified Theory of Acceptance and Use of Technology2) yang dikembangkan oleh Venkatesh et. al. (2012). Terdapat tujuh konstruk yang mempengaruhi Minat Pemanfaatan yaitu Ekspektasi Kinerja (performance expectancy), Ekspektasi Usaha (effort expectancy), Pengaruh Sosial (social influence), Kondisi Pemfasilitasi (facilitating conditions), Motivasi Hedonik (hedonic motivation), Nilai Harga (price value), Kebiasaan (habit). Terdapat juga dua konstruk yang bisa langsung mempengaruhi Penggunaan TI yaitu Kondisi Pemfasilitasi (facilitating conditions) dan Kebiasaan (habit). Berbeda dari Venkatesh, dalam penelitian ini tidak disertakan variabel moderasi. Dalam model penelitian ini juga terdapat variabel moderasi, yaitu Pengalaman (experience). Variabel moderasi Gender (kelamin) dan Umur (age) tidak dimasukkan karena penelitian ini dilakukan kepada responden, yaitu nasabah BCAyang sangat heterogen. Sedangkan variabel Pengalaman (experience) juga tidak disertakan karena peneliti berasumsi bahwa responden mempunyai level yang sama.

Metode analisis data yang digunakan untuk membuktikan hipotesis yang diajukan dalam penelitian ini menggunakan Generalized Structured Component Analysis (GSCA). Tenehaus (2008 dalam Solimun, 2012) mengatakan bahwa GSCA adalah metode baru SEM 
berbasis komponen, sangat penting dan dapat digunakan untuk perhitungan skor (bukan skala) dan juga dapat diterapkan pada sampel yang sangat kecil. Di samping itu, GSCA dapat digunakan pada model struktural yang melibatkan variabel dengan indikator refleksif dan atau formatif. Kegunaan GSCA adalah untuk mendapatkan model struktural yang powerfull guna tujuan konfirmasi. Oleh karena itu, metode GSCA adalah setara dengan analisis model struktural berbasis kovarians (SEM). Dengan demikian analisis GSCA juga powerfull untuk menguji model berbasis teori, atau dengan kata lain untuk mengkonfirmasi teori tentang hubungan antar variabel yang terdapat di dalam model struktural (Solimun, 2012).

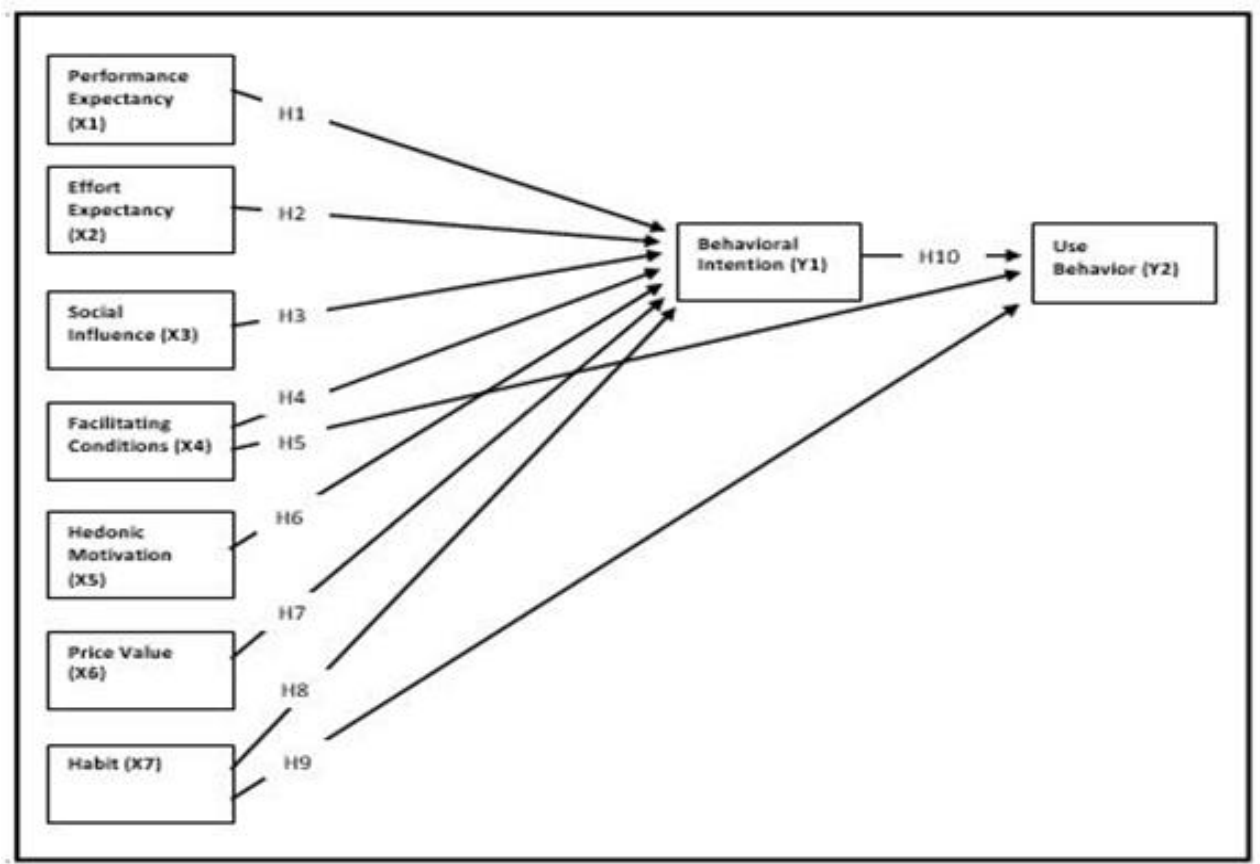

sumber: Penulis (2020)

\section{Gambar 4. Model Hipotesis}

\section{HASIL DAN PEMBAHASAN}

Hasil pengujian validitas untuk item pernyataan yang digunakan dalam mengukur variabel menunjukkan nilai korelasi yang lebih besar dari nilai r-tabel yang ditentukan. Dengan demikian dapat dikatakan bahwa seluruh item pernyataan yang digunakan dalam mengukur variabel tersebut telah menunjukkan tingkat ketepatan yang cukup baik (valid). Sedangkan pengujian reliabilitas seluruh item yang digunakan dalam mengukur variabel dependent dan independent menghasilkan koefisien reliabilitas (cronbach's alpha) diatas 
0.6 sehingga dapat dikatakan bahwa instrumen yang digunakan untuk mengukur seluruh variabel tersebut dinyatakan memiliki reliabilitas yang tinggi. Dengan kata lain instrumen yang digunakan tersebut telah menunjukkan konsistensi pengukuran pada semua respondennya.

Tabel 1. Model FIT GSCA

\begin{tabular}{|c|c|}
\hline \multicolumn{2}{|c|}{ Model Fit } \\
\hline FIT & 0.623 \\
\hline AFIT & 0.617 \\
\hline GFI & 0.877 \\
\hline SRMR & 0.321 \\
\hline NPAR & 100 \\
\hline
\end{tabular}

sumber: Penulis (2020)

FIT menunjukkan varian total dari semua variabel yang dapat dijelaskan oleh model tertentu. Nilai FIT berkisar dari 0 sampai 1. Jadi, model yang terbentuk dapat menjelaskan semua variabel yang ada sebesar 0.623. Keragaman Ekspektasi Kinerja, Ekspektasi Usaha, Pengaruh Sosial, Kondisi Pemfasilitasi, Motivasi Hedonik, Nilai Harga, Kebiasaan, Minat Pemanfaatan dan Penggunaan yang dapat dijelaskan oleh model adalah sebesar $62.3 \%$ dan sisanya (37.7\%) dapat dijelaskan oleh variabel yang lain. Artinya, jika dilihat dari nilai FIT yang diperoleh, model yang terbentuk dapat dikatakan bagus. Semakin besar nilai FIT yang diperoleh maka model yang ada akan semakin bagus.

Adjusted dari FIT hampir sama dengan FIT. Namun, karena variabel yang mempengaruhi Proses Keputusan Pembelian tidak hanya satu sehingga akan lebih baik apabila interpretasi tentang ketepatan model menggunakan FIT yang sudah terkoreksi atau menggunakan AFIT. Karena semakin banyak variabel yang mempengaruhi maka nilai FIT semakin besar karena proporsi keragaman juga akan meningkat sehingga untuk menyesuaikan dengan variabel yang ada dapat menggunakan FIT yang sudah terkoreksi. Jika dilihat dari nilai AFIT, keragaman Ekspektasi Kinerja, Ekspektasi Usaha, Pengaruh Sosial, Kondisi Pemfasilitasi, Motivasi Hedonik, Nilai Harga, Kebiasaan, Minat Pemanfaatan dan Penggunaan yang dapat dijelaskan oleh model adalah sebesar $61.7 \%$ dan 
sisanya (38.3\%) dapat dijelaskan oleh variabel yang lain. Artinya, jika dilihat dari nilai AFIT yang diperoleh, model yang terbentuk bagus.

GFI (Unweighted least-squares) dan SRMR (standardized root mean square residual). Keduanya sebanding dengan perbedaan antara kovarian sampel dan kovarian yang diproduksi oleh pendugaan parameter GSCA. GFI dekat dengan nilai 1 dan nilai-nilai SRMR mendekati 0 dapat diambil sebagai indikasi cocok. Pada permasalahan ini nilai $\mathrm{SRMR}=0,321$ sehingga model yang terbentuk dapat dikatakan telah sesuai. Data stastistik juga menunjukkan nilai GFI = 0,877 maka model dikatakan sesuai.

Hipotesis 1: Ekspektasi Kinerja terhadap Minat Pemanfaatan

Hipotesis H1 menyatakan bahwa Ekspektasi Kinerja berpengaruh signifikan terhadap Minat Pemanfaatan. Hasil pengujian model menggunakan GSCA menunjukkan bahwa hasil positif dan signifikan dengan nilai critical rasio sebesar 2.35 dan koefisien jalur sebesar 0.611, sehingga dapat disimpulkan bahwa Ekspektasi Kinerja memiliki pengaruh yang signifikan dengan Minat Pemanfaatan. Hasil penelitian ini sejalan dengan hasil penelitian Mei Liong (2012) dan Hormati (2012). Hasil penelitian mendukung hasil penelitian Venkatesh et. al. (2003) Dimana penelitian dilakukan dengan model lapangan longitudinal dengan menggunakan empat organisasi yang sedang memperkenalkan suatu TI di tempat kerja. Venkatesh et. al. (2003) menemukan bahwa variabel Ekspektasi Kinerja merupakan prediktor yang kuat dari Niat Keperilakuan sistem informasi dalam setting sukarela maupun wajib. Gender diprediksikan memoderasi pengaruh Ekspektasi Kinerja terhadap Minat Pemanfaatan.

Hipotesis 2: Ekspektasi Usaha terhadap Minat Pemanfaatan

Hipotesis H2 menyatakan bahwa Ekspektasi Usaha berpengaruh signifikan terhadap Minat Pemanfaatan. Hasil pengujian memperoleh bukti empiris bahwa $\mathrm{H} 2$ berpengaruh positif dan signifikan. Artinya, semakin tinggi Ekspektasi Usaha semakin tinggi pula Minat Pemanfaatan. Hasil pengujian model menggunakan GSCA menunjukkan bahwa hasil pengujian berpengaruh positif dan signifikan dengan nilai critial ratio sebesar 3.15 dan koefisien jalur sebesar 0.724. Hal ini konsisten dengan hasil penelitian Venkatesh (2003), Mei Ling Keong (2012), dan Hormati (2012). Venkatesh (2003) menjelaskan bahwa 
Ekspektasi Usaha merupakan tingkat kemudahan Perilaku Menggunakan TI yang akan dapat mengurangi upaya (tenaga dan waktu) individu dalam melakukan pekerjaannya. Kalau TI mudah digunakan, usaha yang dilakukan tidak akan terlalu tinggi dan sebaliknya jika suatu TI sulit digunakan, diperlukan usaha yang tinggi untuk menggunakannya. Menurut Mei Ling Keong (2012) Ekspektasi Usaha menjadi determinan Minat Pemanfaatan.

Hipotesis 3: Faktor Sosial terhadap Minat Pemanfaatan

Hipotesis H3 menyatakan bahwa Pengaruh Sosial berpengaruh signifikan terhadap Minat Pemanfaatan. Hasil pengujian memperoleh bukti empiris bahwa H3 berpengaruh signifikan. Artinya, semakin tinggi Pengaruh Sosial semakin tinggi pula Minat Pemanfaatan. Hasil pengujian model menggunakan GSCA menunjukkan bahwa hasil pengujian berpengaruh signifikan dengan nilai critial ratio sebesar 2.31 dan koefisien jalur sebesar 0.611. Hasil penelitian Venkatesh et. al. (2003), Sedana (2012), Mei Ling Keong (2012), dan Hormati (2012). Sedana (2012) menjelaskan bahwa Faktor Sosial memberikan pengaruh yang besar terhadap Perilaku Menggunakan. Beberapa studi yang lain juga menunjukkan bukti empiris bahwa Pengaruh Sosial berpengaruh positif terhadap niat individu untuk menggunakan sistem informasi berbasis teknologi. Bukti empiris ini memiliki implikasi bahwa individu akan cenderung menggunakan TI jika individu lain yang dianggap penting baginya menggunakan TI juga.

Hipotesis 4: Kondisi Pemfasilitasi terhadap Minat Pemanfaatan

Hipotesis H4 menyatakan bahwa Kondisi Pemfasilitasi berpengaruh signifikan terhadap Minat Pemanfaatan. Hasil pengujian memperoleh bukti empiris bahwa H4 berpengaruh positif dan signifikan. Artinya, semakin tinggi Kondisi Pemfasilitasi semakin tinggi pula Minat Pemanfaatan. Hasil pengujian model menggunakan GSCA menunjukkan bahwa hasil pengujian berpengaruh signifikan dengan nilai critial ratio sebesar 2.58 dan koefisien jalur sebesar 0.657. Hal ini konsisten dengan hasil penelitian Venkatesh (2003), Sedana (2012), Muliati (2010), dan Mei Ling Keong (2012). Bukti empiris penelitian ini memiliki implikasi bahwa BCA seharusnya menyediakan fasilitas pendukung untuk penggunaan mobile banking. Penelitian ini berdasarkan konteks penggunaan mobile 
banking untuk nasabah BCA mendapat bukti empiris yang konsisten dengan penelitianpenelitian sebelumnya. Dengan demikian dapat disimpulkan bahwa kondisi-kondisi pemfasilitasi merupakan faktor determinan perilaku penggunaan TI.

Hipotesis 5: Kondisi Pemfasilitasi terhadap Penggunaan

Hipotesis H5 menyatakan bahwa Kondisi Pemfasilitasi berpengaruh signifikan terhadap Penggunaan. Hasil pengujian memperoleh bukti empiris bahwa H5 berpengaruh positif dan signifikan. Artinya, semakin tinggi Kondisi Pemfasilitasi semakin tinggi pula Penggunaan. Hasil pengujian model menggunakan GSCA menunjukkan bahwa hasil pengujian berpengaruh signifikan dengan nilai critial ratio sebesar 3.57 dan koefisien jalur sebesar 0.758. Hal ini konsisten dengan hasil penelitian Amanullah (2014) dan Laksana (2015).Amanullah (2014) dalam penelitiannya pada nasabah BCA di kota Semarang menemukan bukti bahwa fasilitas merupakan faktor penting bagi penggunaan. Bukti empiris yang lain juga menunjukkan bahwa kemudahan fasilitas yang diberikan oleh BRI berpengaruh positif dan signifikan pada penggunaan m-banking bagi nasabahnya (Laksana, 2015).

Hipotesis 6: Motivasi Hedonik terhadap Minat Pemanfaatan

Hipotesis H6 menyatakan bahwa Motivasi Hedonik berpengaruh signifikan terhadap Minat Pemanfaatan. Hasil pengujian memperoleh bukti empiris bahwa H6 berpengaruh positif dan signifikan. Artinya, semakin tinggi Motivasi Hedonik semakin tinggi pula Minat Pemanfaatan. Hasil pengujian model menggunakan GSCA menunjukkan bahwa hasil pengujian berpengaruh signifikan dengan nilai critial ratio sebesar 2.17 dan koefisien jalur sebesar 0.608. Hasil penelitian ini sejalan dengan hasil penelitian Venkatesh (2003).Motivasi Hedonik didefinisikan sebagai kesenangan atau kesenangan yang didapat dari penggunaan teknologi, dan telah dibuktikan memainkan sebuah peran penting dalam menentukan penerimaan dan penggunaan teknologi (Venkatesh, 2003). Dalam penelitian sistem informasi, motivasi hedonik (dikonseptualisasikan sebagai kenikmatan yang dirasakan) telah ditemukan mempengaruhi teknologi penerimaan dan penggunaan secara langsung. Dalam konteks konsumen, motivasi hedonik juga telah ditemukan faktor penentu penting penerimaan dan penggunaan teknologi. 
Hipotesis 7: Nilai Harga terhadap Minat Pemanfaatan

Hipotesis H7 menyatakan bahwa Nilai Harga berpengaruh positif non signifikan terhadap Minat Pemanfaatan. Hasil pengujian memperoleh bukti empiris bahwa H7 berpengaruh positif tapi tidak signifikan. Artinya, semakin tinggi Nilai Harga semakin tinggi pula Minat Pemanfaatan. Hasil pengujian model menggunakan GSCA menunjukkan bahwa hasil pengujian berpengaruh signifikan dengan nilai critial ratio sebesar 1.14 dan koefisien jalur sebesar 0.355 Hal ini berbeda dengan hasil penelitian Venkatesh (2003). Venkatesh menemukan bahwa struktur biaya dan harga mungkin memiliki dampak signifikan pada penggunaan teknologi konsumen.Nilai Harga berarti positif apabila manfaat menggunakan teknologi dirasakan menjadi lebih besar dari biaya, sehingga Nilai Harga tersebut dampak positif pada Minat Pemanfaatan. Dengan demikian, Venkatesh menambahkan Nilai Harga sebagai prediktor Minat Pemanfaatan untuk menggunakan teknologi.

Hipotesis 8: Kebiasaan terhadap Minat Pemanfaatan

Hipotesis H8 menyatakan bahwa Kebiasaan berpengaruh positif non signifikan terhadap Minat Pemanfaatan. Hasil pengujian memperoleh bukti empiris bahwa H8 berpengaruh positif tapi tidak signifikan. Artinya, semakin tinggi Kebiasaan semakin tinggi pula Minat Pemanfaatan. Hasil pengujian model menggunakan GSCA menunjukkan bahwa hasil pengujian berpengaruh signifikan dengan nilai critial ratio sebesar 1.38 dan koefisien jalur sebesar 0.372. Hal ini berbeda dengan hasil penelitian Venkatesh (2003). Data dari statistik deskriptif dan pengujian loading factor dengan GSCA menunjukkan bahwa Indikator menjadi kebiasaan (X7.1) memperoleh skor critical ratio sebesar 53.37 serta estimasi 0,694. Indikator harus menggunakan (X7.3) memperoleh skor critical ratio71.9 dan estimasi 0,817. Indikator kecanduan menggunakan (X7.2) loading factor dengan critical ratio tertinggi dibanding indikator yang lain dalam variabel Kebiasaan sebesar 78.08 dan estimasi 0.879. Indikator terakhir yaitu natural menggunakan (X7.4) memperoleh skor critical ratio53.37 dan estimasi 0,694.

155 | C A P I T A L, V O L U ME 3, N O M O R 2, MA RE T 2020 
Hipotesis 9: Kebiasaan terhadap Penggunaan

Hipotesis H9 menyatakan bahwa Kebiasaan berpengaruh signifikan terhadap Penggunaan. Hasil pengujian memperoleh bukti empiris bahwa $\mathrm{H} 9$ berpengaruh positif dan signifikan. Artinya, semakin tinggi Kebiasaan semakin tinggi pula Penggunaan. Hasil pengujian model menggunakan GSCA menunjukkan bahwa hasil pengujian berpengaruh signifikan dengan nilai critial ratio sebesar 3.49 dan koefisien jalur sebesar 0.749. Hal ini konsisten dengan hasil penelitian Venkatesh (2003). Venkatesh (2003) menyatakan bahwa proses pemicu kebiasaan (yaitu, isyarat proses and asosiasi) menjadi penting dalam menentukan efek kebiasaan selanjutnya pada niat baik tingkah laku atau penggunaan. Jika konsumen melihat perubahan lingkungan relatif stabil, hubungan antara isyarat stimulus dan niat atau tindakan bisa jadi terjadi dan dipicu. Jika tidak, perilaku konsumen mungkin kurang atau tidak tunduk pada kontrol kebiasaan.

Hipotesis 10: Minat Pemanfaatan terhadap Penggunaan

Hipotesis H10 menyatakan bahwa Minat Pemanfaatan berpengaruh signifikan terhadap Penggunaan. Hasil pengujian memperoleh bukti empiris bahwa H10 berpengaruh positif dan signifikan. Artinya, semakin tinggi Minat Pemanfaatan semakin tinggi pula Penggunaan. Hasil pengujian model menggunakan GSCA menunjukkan bahwa hasil pengujian berpengaruh signifikan dengan nilai critial ratio sebesar 3.74 dan koefisien jalur sebesar 0.832. Pengujian loading factor dengan GSCA menunjukkan hal yang sama. Indikator ingin menggunakan (Y1.1) memperoleh nilai critical ratio tertinggi diantara indikator lainnya dalam variabel Minat Pemanfaatan yakni sebesar 82.93 serta estimasi 0,843. Hal ini konsisten dengan hasil penelitian Venkatesh, et al (2003), Sedana (2012), Muliati (2010), Mei Ling Keong (2012), dan Hormati (2012). 
Tabel 2. Pengujian Structural Model

\begin{tabular}{|c|c|c|c|}
\hline \multicolumn{4}{|l|}{ Path Coefficients } \\
\hline & Estimate & SE & $\mathbf{C R}$ \\
\hline Ekspektasi Kinerja-> Minat Pemanfaatan & 0.611 & 0.235 & $2.32 *$ \\
\hline Ekspektasi Usaha-> Minat Pemanfaatan & 0.724 & 0.420 & $3.15^{*}$ \\
\hline Faktor Sosial-> Minat Pemanfaatan & 0.611 & 0.229 & $2.31 *$ \\
\hline Kondisi Pemfasilitasi-> Minat Pemanfaatan & 0.657 & 0.211 & $2.58 *$ \\
\hline Kondisi Pemfasilitasi-> Penggunaan & 0.758 & 0.436 & $3.57 *$ \\
\hline Motivasi Hedonik-> Minat Pemanfaatan & 0.608 & 0.190 & $2.17 *$ \\
\hline Nilai Harga-> Minat Pemanfaatan & 0.355 & 0.109 & 1.14 \\
\hline Kebiasaan-> Minat Pemanfaatan & 0.372 & 0.111 & 1.38 \\
\hline Kebiasaan-> Penggunaan & 0.749 & 0.461 & $3.49 *$ \\
\hline Minat Pemanfaatan -> Penggunaan & 0.832 & 0.529 & $3.74 *$ \\
\hline
\end{tabular}

sumber: Penulis (2020)

Berdasarkan hasil pengujian hipotesis penelitian dengan judul "Analisis Penerimaan teknologimobile banking terhadap use behavior melalui pendekatan Model UTAUT 2 (Studi pada nasabah BCA cabang Malang)", maka ditemukan hasil penelitian dengan model empiris yang ditunjukkan dengan model Gambar berikut ini:

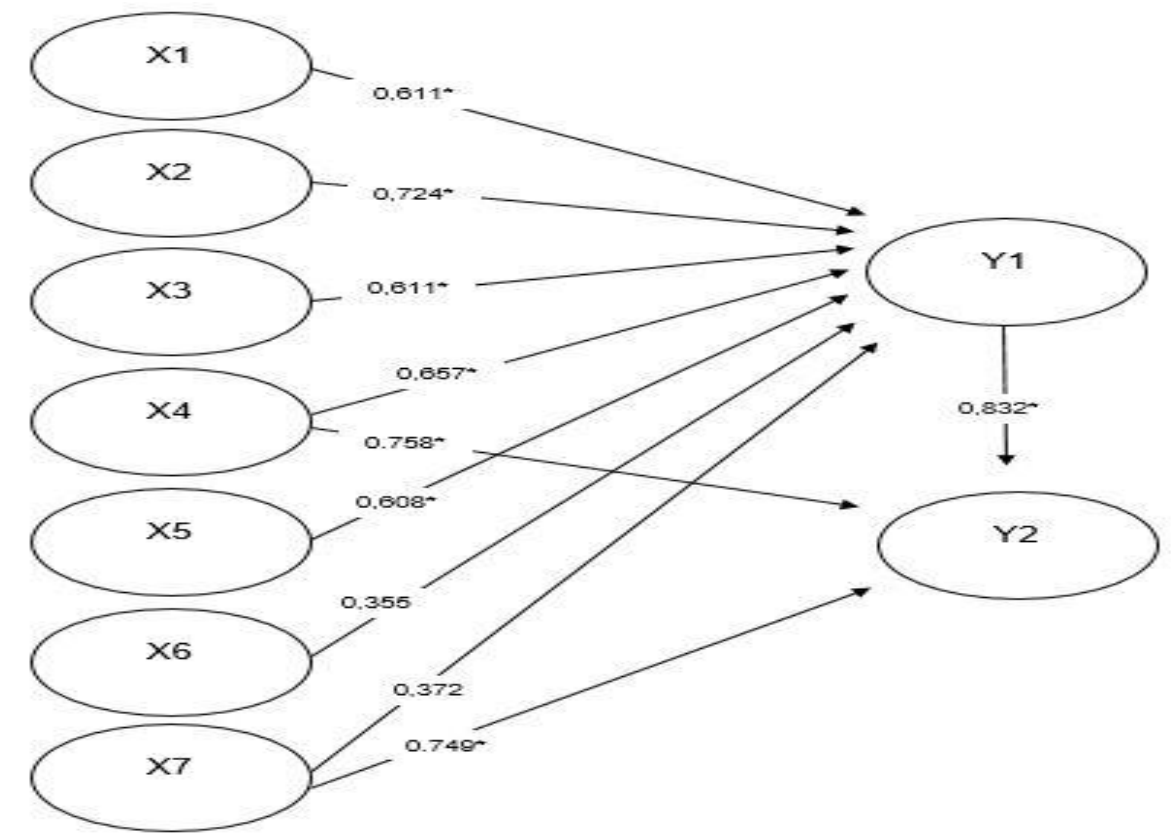

sumber: Penulis (2020)

Gambar 5. Model Empiris Penelitian 


\section{E. SIMPULAN}

Dari hasil penelitan dengan judul Analisis Penerimaan Teknologi Mobile Banking Terhadap Use Behavior Melalui Pendekatan Model UTAUT 2 (Studi Pada Nasabah KCU BCA Malang) menggunakan alat analisis GSCA dapat disimpulkan bahwa semua variabel yang diuji dalam model mempunyai hubungan yang positif. Dapat dikatakan bahwa jika salah satu variabel mengalami kenaikan, maka memberikan pengaruh kenaikan juga pada variabel yang lain. Dari 10 hubungan yang diteliti, terdapat 2 hubungan yang positif tapi non signifikan. Yaitu hubungan antara Nilai Harga terhadap Minat Pemanfaatan serta hubungan antara Kebiasaan terhadap Minat Pemanfaatan.

Berdasarkan hasil penelitian, saran yang perlu dipertimbangkan yakni Peneliti selanjutnya dapat melakukan pengumpulan data dengan menggunakan penggabungan instrumen lain selain kuesioner, seperti wawancara mendalam dengan responden maupun dengan pihak manajemen BCA sehingga dapat diperoleh informasi dan gambaran variabelvariabel dan hubungannya secara lebih jelas. Berdasarkan keterbatasan penelitian di atas, peneliti selanjutnya disarankan untuk mengambil obyek penelitian dan jumlah sampel yang berbeda untuk mengkaji model secara lebih mendalam, serta diharapkan akan memperoleh hasil yang maksimal.

\section{DAFTAR PUSTAKA}

Keller, T. E., Cusick, G. R., \& Courtney, M. E. (2007). Approaching the transition to adulthood: Distinctive profiles of adolescents aging out of the child welfare system. Social Services Review, 81, 453- 484.

Amanullah, Bastian. 2014. Pengaruh Persepsi Manfaat, Kemudahan Penggunaan, Dan Kepercayaan Terhadap Sikap Positif Penggunaan Layanan Mobile Banking (Survey Pada Nasabah Bank BCA Semarang). Fakultas Ekonomi dan Bisnis Universitas Diponegoro, tidak dipublikasikan.

Davis, F.D. 1989. Perceived Usefulness, Perceived Ease of Use, and User Acceptance of Information Technology. MIS Quarterly. 13: 319-340.

DeLone, William H. dan McLean, Ephraim R. 2003. The DeLone and McLean Model of Information Systems Success: A Ten-Year Update. Journal of Management Information Systems / Spring 2003, Vol. 19, No. 4, pp. 9-30.

Hormati, Asrudin. 2012. Pengujian Model Unified Theory of Acceptance and Use of Technology (UTAUT) dalam Pemanfaan Sistem Informasi Keuangan Daerah Berbasis Teknologi Komputer (Studi Empiris pada Pemerintahan Provinsi Maluku Utara). Program Magister Ilmu Akuntansi, Fakultas Ekonomi dan Bisnis Universitas Brawijaya, tidak dipublikasikan. 
Laudon, Kenneth C. dan Laudon, Jane P. 2005. Sistem Informasi Manajemen: Mengelola Perusaahan Digital, Edisi 8, diterjemahkan oleh ErwinPhillippus. ANDI. Yogyakarta.

Laksana, Giga Bawa. 2015. Pengaruh Persepsi Kemanfaatan, Persepsi Kemudahan Penggunaan, Persepsi Resiko Dan Persepsi Kesesuaian Terhadap Minat Menggunakan Mobile Banking (Studi Pada Nasabah Bank Rakyat Indonesia (Bri) Kantor Cabang Rembang, Jawa Tengah). Jurnal Administrasi Bisnis, Vol. 26, No. 2, pp. 4-7.

Mei Ling Keong, Thurasamy Ramayah, Sherah Kurnia, Lo May Chiun. 2012. "Explaining intention to use an enterprise resource planning (ERP) system: an extension of the UTAUT model", Business Strategy Series, Vol. 13 Iss: 4 pp. 173 - 180.

Muliati, Niswah. 2010. Pengaruh Perceived Usefulness, Perceived Ease of Use, Attitude Toward Using, dan Behavior Intention to Use, terhadap Actual System Use dalam Implementasi Teknologi Enterprise Resource Planning (ERP) System (Survei pada End-User ERP System di PT Semen Gresik).. Tesis. Program Magister Ilmu Administrasi Bisnis, Fakultas Ilmu Administrasi. Universitas Brawijaya, tidak dipublikasikan.

O’Brief, James A. 2008. Pengantar Sistem Informasi, penerjemah: Dewi Fitriasari, dkk. SalembaEmpat. Jakarta.

Singarimbun, M dan Effendi. 1995. Metode Penelitian Survei, edisi revisi. LP3ES.Jakarta.

Solimun. 2012. Penguatan Confirmatory Reseach Pemodelan Persamaan Struktural Generalized Structured Component Analysis GSCA. Program Studi Statistika FMIPA Universitas Brawijaya. Malang.

Sugiyono. 2010. Metode Penelitian Bisnis: Pendekatan Kuantitatif, Kualitatif, dan R\&D, edisi kelima belas. Alfabeta. Bandung.

Venkatesh, V. Morris, M.G., Davis G.B., dan Davis, F.G. 2003. User Acceptance of Information Technology: Toward a Unified View. MIS Quarterly, 27 (3): 425 - 278.

Zhao, Tao dan Lu, Yaobin. 2010. Integrating TTF and UTAUT to explain mobile banking user adoption. Computer in Human Behavior, Vol. 26, pp. 760-767. 